Фармацевтичний менеджмент, маркетинг та логістика

Pharmaceutical management, marketing and logistics

Рекомендована д. фрармац. наук, профр. Т. А. Грошовим

УДК 615.242: 339.138

DOI 10.11603/2312-0967.2018.1.8620

\title{
ДОСЛІДЖЕННЯ АСОРТИМЕНТУ ЛІКАРСЬКИХ ЗАСОБІВ ДЛЯ МІСЦЕВОГО ЗАСТОСУВАННЯ В СТОМАТОЛОГІї
}

\author{
() Г. Р. Козир, М. М. Васенда, І. Р. Міц, Р. Л. Козир
}

\author{
ДВНЗ «Тернопільський державний медичний університет імені І. Я. Горбачевського \\ МОЗ України» \\ kozyr.gr@gmail.com
}

\begin{abstract}
Мета роботи. Вивчити асортимент лікарських засобів для місцевого застосування у стоматології, які представлені на фрармацевтичному ринку України та доступні споживачам шляхом порівняння асортименту за останні 5 років. Матеріали і методи. Асортимент лікарських засобів і динаміку його зміни впродовж 5 років вивчали за допомогою доступних електронних ресурсів та аналітичних систем.

Результати й обговорення. Встановлено країни, які експортують на український фрармацевтичний ринок лікарські засоби досліджуваної групи. Визначено основних вітчизняних виробників досліджуваного асортименту лікарських засобів. При сегментації ринку препаратів за лікарськими фрормами встановлено, що іноземні виробники постачають на ринок гелі та розчини, тоді як вітчизняні фрірми віддають перевагу лікарській рослинній сировині. Висновки. Проведені дослідження дають підстави стверджувати, що розробка лікарських препаратів у срормі гелю є перспективною та необхідною.
\end{abstract}

Ключові слова: засоби для застосування в стоматології; аналіз асортименту; фармацевтичний ринок.

Вступ. Одне з перших місць серед найпоширеніших захворювань організму займають хвороби ротової порожнини. Згідно з даними ВООЗ близько 80 \% дорослого та 65 \% дитячого віку населення страждають від захворювань пародонта [1, 2]. Етіологічними чинниками запальних процесів ротової порожнини можуть бути такі загальні порушення організму, як захворювання серцево-судинної та ендокринної систем, захворювання крові, токсикоз у вагітних тощо. Також важливе значення має стан гігієни ротової порожнини, наявність м'яких та твердих зубних відкладень, продуктів життєдіяльності мікроорганізмів і бактерій, які руйнують кісткову тканину та тканини пародонта [1, 3].

На сьогодні важливою складовою лікувально-профрілактичних заходів низки патологічних станів у стоматологічній практиці є лікарські засоби (ЛЗ) місцевої дії. Численність фракторів патогенезу хвороб пародонта зумовлює характер їх лікування - комплексність, а саме біологічно активні речовини лікарських засобів спроможні чинити комплексну, різноспрямовану дію на ланки патогенезу означених захворювань [4]. Внаслідок швидкого прогресування, значного поширення актуальним $€$ вивчення асортиментного складу лз з метою розширення схем лікування, пошуку нових ефективних ЛЗ [5, 6].

У зв'язку з реєстрацією нових ЛЗ, поповненням переліку препаратів Державного реєстру і оновленням діючих, препарати стоматологічної спрямованості потребують різнобічного аналітичного вивчення, що сприяє необхідності пошуку нових дієвих речовин та створенню на їх основі ефективних ЛЗ.

Мета роботи - вивчити асортимент ЛЗ для місцевого застосування в стоматології, які представлені на фрармацевтичному ринку України та доступні споживачам шляхом порівняння асортименту за останні 5 років.

Матеріали і методи. Теоретичний арсенал досліджуваних Л3 вивчали з використанням контент-аналізу Державного реєстру готових ЛЗ щодо ліків для місцевого застосування в стоматології, які згідно 3 класифрікаційною системою АТС належать до групи лз А01А «Засоби для застосування в стоматології» $\mathrm{i}$ складають підгрупи А01АВ «Протимікробні та антисептичні препарати для місцевого застосування в стоматології« та A01AD «Інші засоби для місцевого застосування в стоматології» $[7,8]$. У ході досліджень застосовано методи сучасного інфрормаційного пошуку, бібліографрічний, системного і порівняльного аналізу, логічний та узагальнення.

Результати й обговорення. Згідно з даними Державного реєстру Л3, станом на 1 травня 2013 р. встановлено, що на українському фрармацевтичному ринку лікарські препарати для місцевого застосування в стоматології були представлені 90 позиціями Л3, 3 яких лікарська рослинна сировина (ЛРС) становить 24 позиції і 66 позицій лікарські препарати (ЛП). Відсоткове співвідношення наведено на рисунку 1.

ISSN 2312-0967. Фармацевтичний часопис. 2018. № 1 

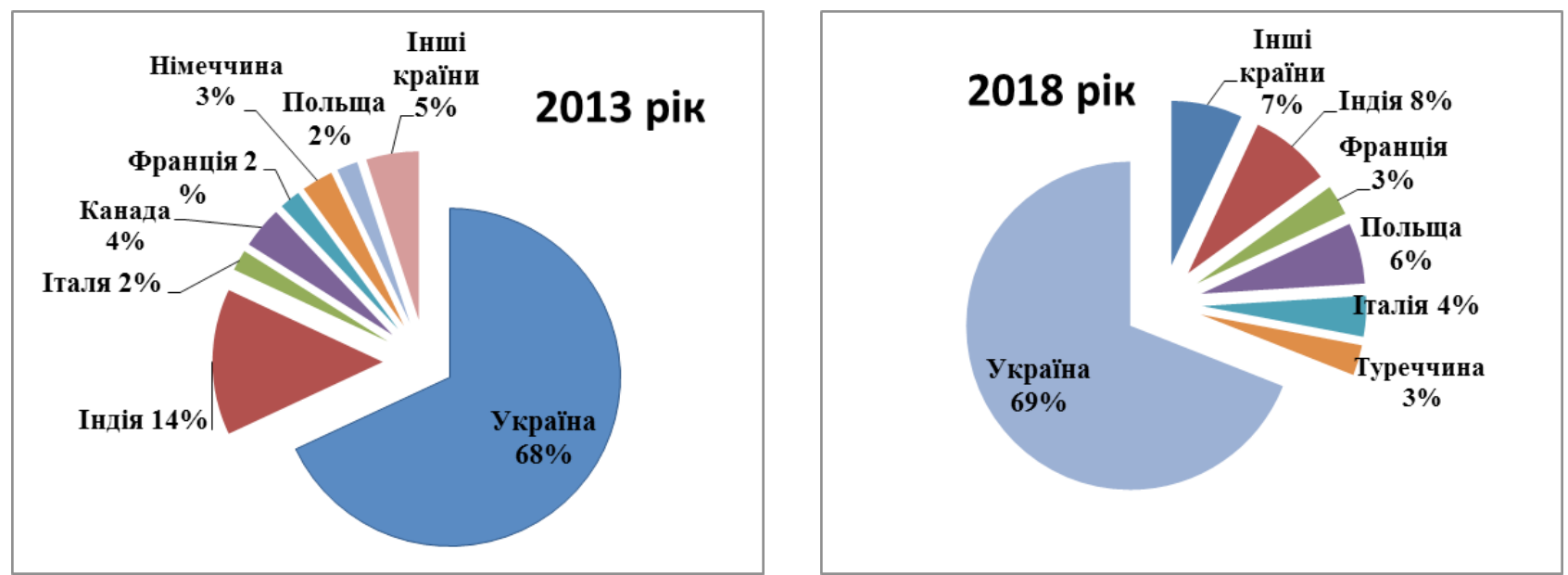

Рис. 1. Розподіл країн-виробників залежно від обсягу представлених на українському фрармацевтичному ринку зареєстрованих засобів для застосування в стоматології.

Протягом 5 років кількість лП для місцевого застосування в стоматології дещо зменшилась. Станом на 1 січня 2018 р. на ринку України офріційно зареєстровано 80 позицій ЛЗ. Змінилась і кон'юктура ринку, так ЛРС становить 21,25 \% і представлена 17 позиціями, тоді як ЛП - 63 позиції, що у відсотках - 78,75 \%.

Для подальших маркетингових досліджень обрано всі позиції Лз.

На першому етапі ми провели аналіз лп для місцевого застосування в стоматології залежно від країни-виробника. За результатами досліджень встановлено, що у 2013 р. в Україні ЛЗ вітчизняного виробництва досліджуваної групи представлені 66 позиціями і 29 позиціями іноземного виробництва.

На початок 2018 р. співвідношення між препаратами вітчизняного та імпортного виробництва у відсотковому еквіваленті фактично не змінилось (69 \% та 31 \% відповідно), причому вітчизняні Лз представлені 55 позиціями, а імпортні - 25 (рис. 1).

Як видно 3 даних рисунка 1, лідери ринку серед іноземних країн-виробників також змінились, дещо змінилась їх частка. Так, кількість ЛЗ, виготовлених в Індії, в 2013 р. становила 14,4 \%, на даний час лише 7,5 \%, тоді як препарати польського виробництва збільшили свою частку 34 до 6,25 \%. Зовсім зникли $з$ фрармацевтичного ринку препарати з Канади, тоді як у 2013 р. вони посідали друге місце серед країн-імпортерів л3 даної групи і постачали 4,4 \%, відсутні препарати, виготовлені в Австрії (1 позиція). Німеччина скоротила кількість препаратів даної групи з 3 до 1 \% і поступилась третьою позицією виробникам 3 Італії, кількість препаратів яких збільшилась до 3,75 \%. Слід зазначити, що на українському фрармацевтичному ринку з'явились препарати досліджуваної групи виробництва Туреччини (2 позиції) та по одному препарату виробництва Вірменії, Болгарії, Нідерландів та Ізраїлю.

Встановлено, що у 2013 р. лідером серед фрірмвиробників Лз для місцевого застосування в ротовій порожнині була фрармацевтична компанія Юнік Фармасьютикал Лабораторіз (Індія), частка продукції якої становила 17,3\% від усіх Л3 іноземного виробництва. Станом на початок 2018 р. лідером серед орірмвиробників даної групи є Енк юб Етікалз Прайвіт Лімітед (Індія), яка забезпечує 16 \% препаратів закордонного виробництва. Детальніше про інших виробників даної групи Л3 наведено у таблицях 1, 2.

У 2013 р. ЛЗ для місцевого застосування у стоматології виготовляють 25 вітчизняних фрармацевтичних підприємств. На початок 2018 р. їх кількість зменшилась до 17, зменшилась і кількість Л3 досліджуваної групи з 61 позиції до 55. На рисунках 2, 3 наведено перелік українських виробників та кількість позицій ЛЗ досліджуваної групи препаратів.

У відсотковому вираженні результати рисунка 2 становлять: 11,5 \% ринку у 2013 р. належали КП Київської обласної ради «Фармацевтична фрабрика» (м. Київ), 9,8 \% ВАТ «Лубнифрарм» (м. Лубни) та по 8,2 \% ринку належали фрірмам - виробникам: ТОВ «Фармацевтична компанія «Здоров'я» (м. Харків), TOB «Тернофрарм (м. Тернопіль), ЗАТ «Ліктрави» (м. Житомир) та ПрАТ Фармацевтична фрабрика «Віола» (м. Запоріжжя).

3 початку 2018 р. змінилися лідери із виробництва Л3 даної групи (рис. 3). 12,7 \% Л3 виготовляє ПрАТ Фармацевтична фрабрика «Віола», Україна, по 6 позицій (10,9 \%) випускають ПАТ «Лубнисрарм» та ТОВ «Тернофрарм», дещо поступається їм Товариство 3 обмеженою відповідальністю «Фармацевтична фрірма «Вертекс»- 9,1 \%.

Наступний етап маркетингових досліджень полягав в аналізі лікарських фрорм (ЛФ) ЛЗ для місцевого застосування в стоматології вітчизняних та іноземних виробників. На рисунку 4 представлені відсоткові співвідношення різних ЛФ препаратів українського виробництва.

Аналіз результатів досліджень свідчить, що вітчизняні виробники у 2013 р. надавали перевагу ЛРС -

ISSN 2312-0967. Pharmaceutical review. 2018. № 1 
Фармацевтичний менеджмент, маркетинг та логістика

Pharmaceutical management, marketing and logistics

Таблиця 1. Розподіл іноземних фрірм-виробників залежно від обсягу представлених на українському фрармацевтичному ринку зареєстрованих ЛЗ для місцевого застосування у стоматології у 2013 р.

\begin{tabular}{|c|l|c|}
\hline № з/п & \multicolumn{1}{|c|}{ Фірма і країна-виробник } & Кількість позицій \\
\hline 1 & Юнік Фармасьютикал Лабораторіз, Індія & 5 \\
\hline 2 & Сінмедик Лабораторіз, Індія & 4 \\
\hline 3 & Азіенде Кіміке Ріуніте Анжеліні Франческо - А.К.Р.А.Ф. - С.п.А, Італія & 2 \\
\hline 4 & Дженом Біотек Пвт. Лтд., Індія & 2 \\
\hline 5 & Фармасайнс Інк, Канада & 4 \\
\hline 6 & Фамар Орлеан, Франція & 1 \\
\hline 7 & Босналек д.Д, Боснія і Герцеговина & 1 \\
\hline 8 & Євролайф Хелткеар Пвт. Лтд, Індія & 1 \\
\hline 9 & Б. Браун Мельзунген АГ, Німеччина & 1 \\
\hline 10 & Груп Фармасьютікалз Лтд, Індія Енк юб Етікалз Прайвіт Лімітед, Індія & 1 \\
\hline 11 & Гесельшарт фрармасьютіше препарати Ленк та Шуппан, Німеччина & 1 \\
\hline 12 & Дойче Хомеопаті-Уніон ДХУ-Арцнайміттель ГмбХ \& Ко. КГ, Німеччина & 1 \\
\hline 13 & Легасі Фармасьютікалз Світселенд ГмбХ, Швейцарія & 1 \\
\hline 14 & Фармзавод Єльфа А.Т, Польща & 1 \\
\hline 15 & Квізда Фарма ГмбХ, Австрія & 1 \\
\hline 16 & ВТО «ЕВА» С.А, Польща & 29 \\
\hline Всього & & \\
\hline
\end{tabular}

Таблиця 2. Розподіл іноземних фрірм-виробників залежно від обсягу представлених на українському фрармацевтичному ринку зареєстрованих ЛЗ для місцевого застосування у стоматології у 2018 р.

\begin{tabular}{|c|l|c|}
\hline № 3/п & \multicolumn{1}{|c|}{ Фірма і країна виробник } & Кількість позицій \\
\hline 1 & Енкґб Етікалз Прайвіт Лімітед, Індія & 4 \\
\hline 2 & Фітофарм Кленка С. А., Польща & 2 \\
\hline 3 & АйСіЕн Польра Жешув Ес.Ей., Польща & 2 \\
\hline 4 & ФАМАР ОРЛЕАН, Франція & 2 \\
\hline 5 & АБДІ ІБРАХІМ Ілач Санаї ве Тіджарет А.Ш., Туреччина & 2 \\
\hline 6 & Азіенде Кіміке Ріуніте Анжеліні Франческо А.К.Р.А.Ф. С.п.А., Італія & 1 \\
\hline 7 & Босналек Д.Д., Боснія і Герцеговина & 1 \\
\hline 8 & ТОВ «Арпімед», Республіка Вірменія & 1 \\
\hline 9 & Дексель Фарма Технолоджиз Лтд., Ізраїль & 1 \\
\hline 10 & Фармзавод Єльфра А.Т., Польща & 1 \\
\hline 11 & ДІШ АГ, Швейцарія & 1 \\
\hline 12 & Легасі Фармасьютікалз Світселенд ГмбХ, Швейцарія & 1 \\
\hline 14 & Дентінокс Гесельшафт фрармасьютіше препарати Ленк та Шуппан, Німеччина & 1 \\
\hline 15 & АТ «Софрарма», Болгарія & 1 \\
\hline 16 & Херкель Б.В., Нідерланди & 1 \\
\hline «Юнік Фармасьютикал Лабораторіз» (відділення фрірми «Дж. Б. Кемікалз енд & 1 \\
\hline
\end{tabular}

частка становить 39 \% (24 позиції), це листки, кора, трава та збір. У відсотковому вираженні листки становлять 45,8 \%, трава та кора по $25 \%$ і найменшу частку займає збір - 4,2 \% від кількості ЛРС.
Також дослідження показало наявність серед ЛФ вітчизняного виробника значної кількості розчинів $25 \%$ (15 позицій) та настойок - $11 \%$ (7 позицій). На фрармацевтичному ринку також присутні такі ЛФ, як

ISSN 2312-0967. Фармацевтичний часопис. 2018. № 1 
Фармацевтичний менеджмент, маркетинг та логістика Pharmaceutical management, marketing and logistics

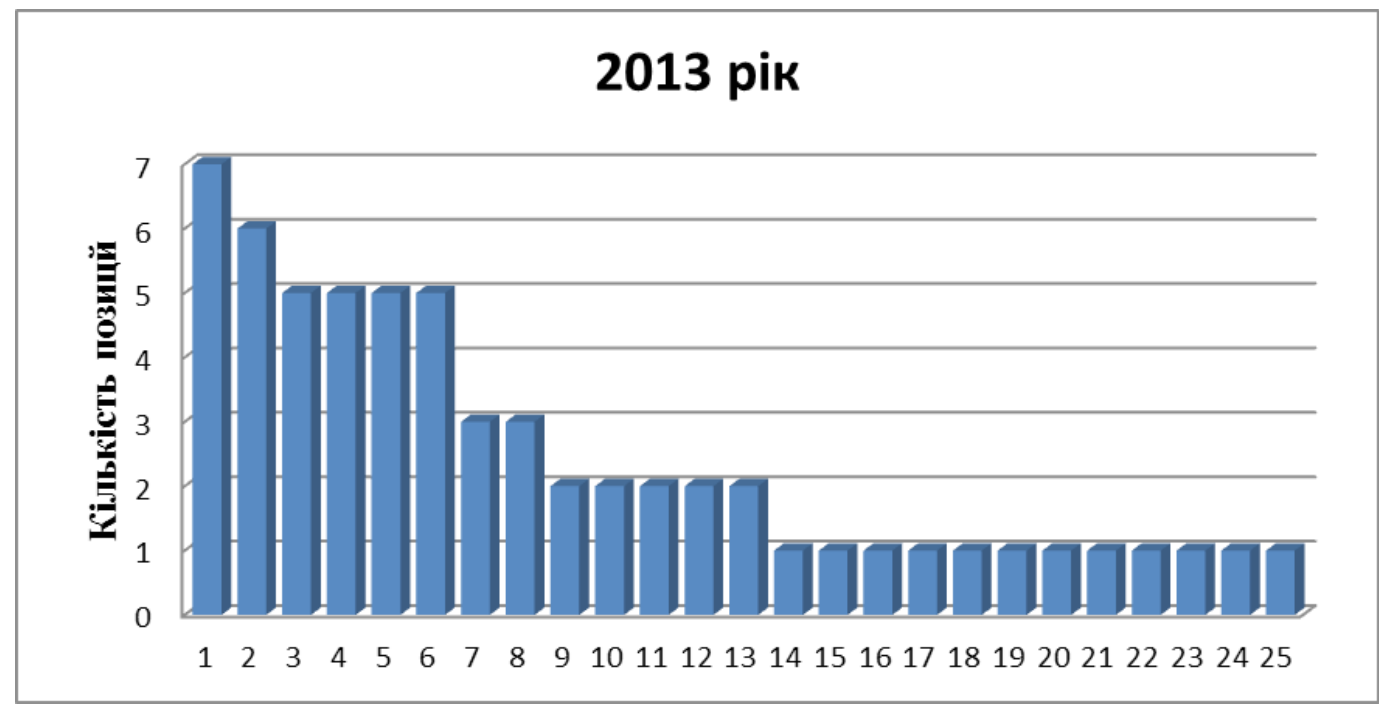

Рис. 2. Розподіл вітчизняних фрірм-виробників залежно від обсягу представлених на українському фармацевтичному ринку зареєстрованих ЛЗ для місцевого застосування у стоматології у 2013 р.: 1 - КП Київської обласної ради «Фармацевтична фрабрика»; 2 - ВАТ «Лубнифрарм»; 3 - ТОВ Фармацевтична компанія «Здоров'я»; 4 - ТОВ «Терносрарм»; 5 - ЗАТ «Ліктрави»; 6 - ПрАТ Фармацевтична фрабрика «Віола»; 7 - ТОВ «Фітолік»; 8 - ПАТ «Фітофрарм»; 9 - ТОВ «Фармацевтична фрабрика»; 10 - ПАТ Хімфрармзавод «Червона зірка»; 11 - ТОВ «Панацея»; 12 - КП «Луганська обласна «Фармація», Фармацевтична фрабрика; 13 - АТ «Стома»; 14 - Дочірнє підприємство «Черкаси-ФАРМА», Україна для ТОВ «Фармлінк»; 15 - ПрАТ «Біофрарма»; 16 - ЗАТ «Інфузія»; 17 - ТОВ «ЮріяФарм»; 18 - ТОВ «Ніко»; 19 - ДП «Фарматрейд»; 20 - ТОВ фрірма «Новофрарм-Біосинтез»; 21 - ТОВ «Фармекс Груп»; 22 - ДП «Експериментальний завод медичних препаратів ІБОНХ НАН України»; 23 - ТОВ «Дослідний завод «ГНЦЛС»; 24 - ЗАТ «Фармнатур»; 25 - ПАТ «Ліки Кіровоградщини».

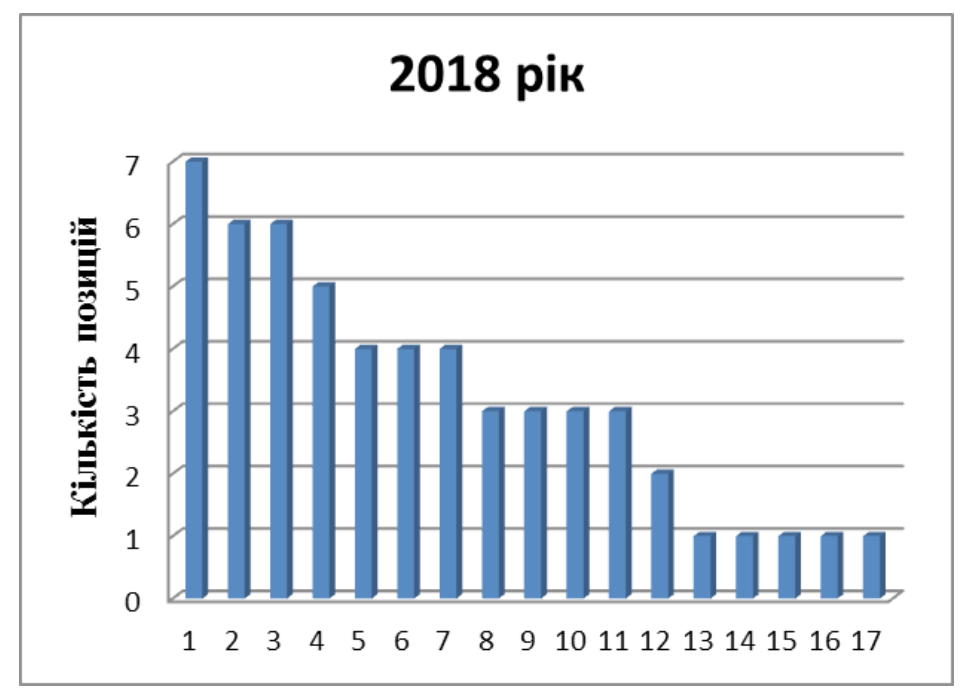

Рис. 3. Розподіл вітчизняних фрірм-виробників залежно від обсягу представлених на українському фрармацевтичному ринку зареєстрованих ЛЗ для місцевого застосування у стоматології у 2018 році: 1 - ПрАТ Фармацевтична фрабрика «Віола»; 2 - ПАТ «Лубнифрарм»; 3 - ТОВ «Тернофрарм»; 4 - ТзОВ «Фармацевтична фрірма «Вертекс»; 5 - ПрАТ «Ліктрави»; 6 - ТзОВ «Фармацевтична компанія «Здоров'я»; 7 - ПРАТ «ФІТОФАРМ»; 8 - ПАТ «Фітофрарм»; 9 - АТ «СТОМА»; 10 - ПАТ «Фармак»; 11 - ТОВ «ДКП «Фармацевтична фрабрика»; 12 - ПрАТ «Технолог»; 13 - ТОВ «Мікрофрарм»; 14 - ДП «Експериментальний завод медичних препаратів ІБОНХ НАН України»; 15 - ПАТ «Хімфрармзавод «Червона зірка»; 16 - ТзОВ «Дослідний завод «ГНЦЛС»; 17 - Спільне українсько-іспанське підприємство «СПЕРКО УКРАЇНА».

краплі та спреї по 5 \%, по 3 \% рідини, таблетки та аерозолі, а також по $2 \%$ - гелі, олії те екстракти.

Як видно з даних рисунків дещо змінився асортимент ЛФ для місцевого застосування в стоматології на початку 2018 року. Частка ЛРС у досліджуваній групі дещо зменшилась і становить 31 \% (17 позицій), причому листя становить 16,4%, трава і кора по 7,3\%.

ISSN 2312-0967. Pharmaceutical review. 2018. № 1 
Фармацевтичний менеджмент, маркетинг та логістика Pharmaceutical management, marketing and logistics

Змінився асортимент ЛФ, кількість розчинів зменшилась до 8 позицій, що у відсотковому еквіваленті становить по 14 \%. Лідером серед ЛФ є спреї, які становлять $16 \%$ ринку вітчизняних ЛЗ цієї групи. Кількість настойок залишилась без змін, проте зріс відсоток гелів до 9 \% (5 позицій) та таблеток до 5 \% (3 позиції).

Як видно 3 даних рисунків 5 дещо змінився і асортимент ЛФ для місцевого застосування в стоматології іноземного виробництва.

Так, у 2013 р. іноземні виробники надавали перевагу гелям - 45 \% (12 позицій) відносно інших ЛФ.
Розчини становили дещо меншу кількість - 35 \% (9 позицій), 12 \% мали спреї (3 позиції), порівну по 4 \% займали льодяники та паста (по 1 позиції).

На початок 2018 р. частка гелів та розчинів для місцевого застосування в стоматології іноземного виробництва стала однаковою - по $32 \%$ (8 позицій), зросла кількість спреїв до 16 \% (4 позиції). На фрармацевтичний ринок України імпортовано 2 позиції таблеток для розсмоктування (8 \%) і по одній позиції дентальна паста, льодяники та вкладки дентальні, що значно розширило асортиментний ряд ЛФ для місцевого застосування в стоматології.
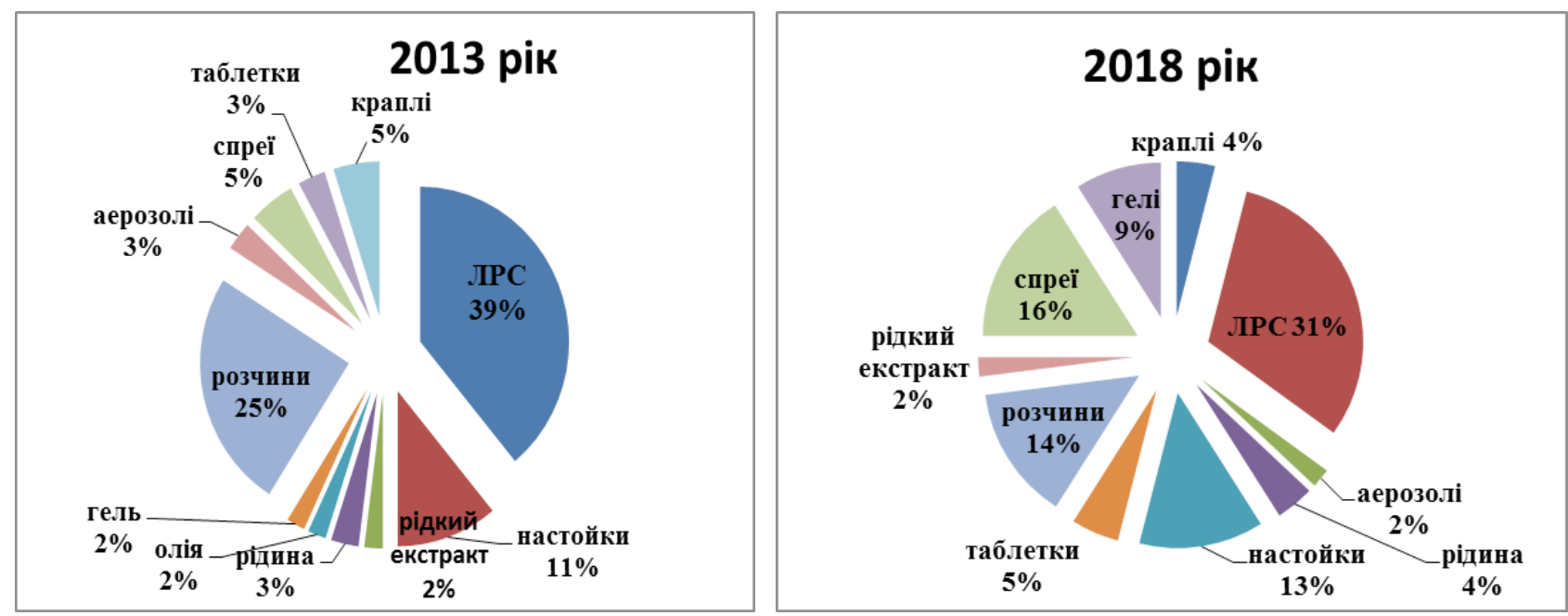

Рис. 4. Співвідношення ЛЗ вітчизняного виробника за лікарською формою у 2013 та 2018 роках.

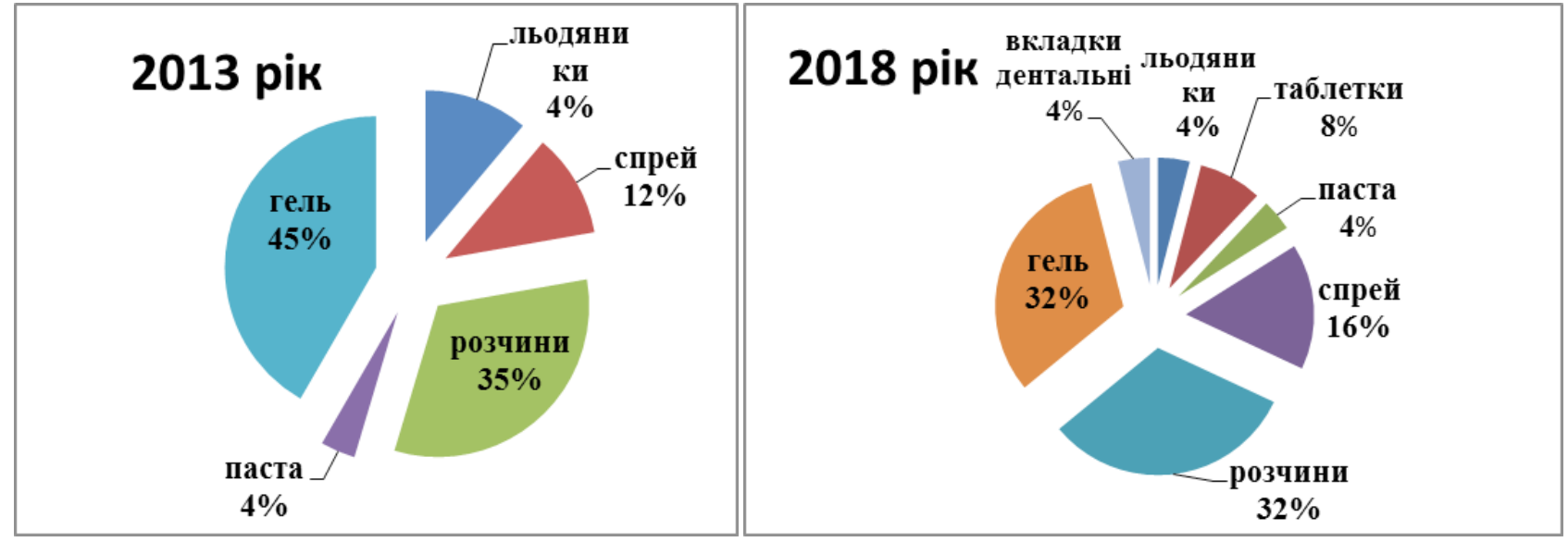

Рис. 5. Співвідношення ЛЗ іноземного виробника за лікарською фрормою.

Висновки. 1. На основі даних інфрормаційного пошуку і аналізу літератури проведено порівняльне вивчення арсеналу лікарських засобів для місцевого застосування в стоматології за останні 5 років та встановлено, що асортимент цих лікарських засобів представлений переважно вітчизняними фрірмами-виробниками.
2. Визначено лідерів серед іноземних та вітчизняних виробників даної групи препаратів.

3. Маркетинговими дослідженнями проведено аналіз та зміни в асортименті лікарських фрорм лікарських засобів для місцевого застосування в стоматології вітчизняних та іноземних виробників. 
Фармацевтичний менеджмент, маркетинг та логістика

Pharmaceutical management, marketing and logistics

\title{
ИССЛЕДОВАНИЯ АССОРТИМЕНТА ЛЕКАРСТВЕННЫХ СРЕДСТВ ДЛЯ МЕСТНОГО ПРИМЕНЕНИЯ В СТОМАТОЛОГИИ
}

\author{
Г. Р. Козыр, М. М. Васенда, И. Р. Миц, Р. Л. Козыр \\ ГВУз «Тернопольский государственный медицинский университет имени И. Я. Горбачевского Мз \\ Украины» \\ kozyr.gr@gmail.com
}

\begin{abstract}
Цель работы. Изучить ассортимент лекарственных средств для местного применения в стоматологии, представленных на орармацевтическом рынке Украины путем сравнения ассортимента за последние 5 лет.

Материалы и методы. Ассортимент лекарственных средств и динамику его изменения в течение 5 лет изучали с помощью доступных электронных ресурсов и аналитических систем.

Результаты и обсуждение. Установлено страны, экспортирующие на украинский фармацевтический рынок лекарственные средства исследуемой группы. Определены основные отечественных производителей исследуемого ассортимента лекарственных средств. При сегментации рынка препаратов за лекарственными фрормами установлено, что иностранные производители поставляют на рынок гели и растворы, тогда как отечественные срирмы предпочитают лекарственное растительное сырье.

Выводы. Проведенные исследования дают основания утверждать, что разработка лекарственных препаратов в форме гелей является перспективной и необходимой.
\end{abstract}

Ключевые слова: средства для применения в стоматологии; анализ ассортимента; фармацевтический рынок.

\section{RESEARCH OF THE ASSORTMENT OF MEDICINAL PRODUCTS FOR LOCAL APPLICATION IN DENTISTRY}

\section{G. R. Kozyr, M. M. Vasenda, I. R. Mits, R. L. Kozyr}

\author{
I. Horbachevsky Ternopil State Medical University \\ kozyr.gr@gmail.com
}

The aim of the work. Examining the range of the assortment of medicines for local use in dentistry, which are presented on the pharmaceutical market of Ukraine and available to consumers by comparing the range over the past 5 years.

Materials and Methods. The range of medicines and the dynamics of its change for 5 years was studied using accessible electronic resources and analytical systems.

Results and Discussion. The countries that export drugs to the Ukrainian pharmaceutical market are established. The main domestic manufacturers of the investigated assortment of medicinal products are determined. When segmentation of the drug market for medicinal forms it is established that foreign manufacturers deliver gels and solutions to the market, while domestic firms prefer medicinal plant raw materials.

Key words: means for use in dentistry; assortment analysis; pharmaceutical market.

\section{Список літератури}

1. Кобець М. М. Вивчення конкурентоспроможності стоматологічних препаратів / М. М. Кобець, Ю. М. Кобець // Науково-технічний прогрес і оптимізація технологічних процесів створення лікарських препаратів: матеріали 5 наук.-практ. конфр. 3 міжнар. участю, 27-28 вересня 2013 р., Тернопіль - Тернопіль : Вид-во «Укрмедкнига». - 2013. - С. 245-246.

2. Інтегральна характеристика інсрекційно-запальних захворювань порожнини рота / А. Л. Мельник, І. М. Довга, Г. Є. Христян [та ін.] // Клінічна та експериментальна патологія. - 2015. - № 1. - С. 215-220.

3. Заболотний Т. Д. Генералізований пародонтит / Т. Д. Заболотний. - Львів : ГалДент, 2011. - 240 с.

4. Дослідження асортименту стоматологічних лікарських засобів, представлених на фрармацевтичному ринку Украї- ни / Л. І. Шульга, Т. С. Безценна, О. Ф. Пімінов [та ін.] // Запорожский медицинский журнал. - 2012. - № 5. - С. 110-113. 5. Лукашів О. І. Дослідження асортименту лікарських засобів на рослинній основі для місцевого застосування в стоматології та лор-практиці / О. І. Лукашів, Л. В. Вронська, І. Л. Бензель // Фармацевтичний часопис. - 2013. - № 1. - C. 146-151.

6. Мазур І. П. Фармакологічні засоби для місцевого лікування тканин пародонту / І. П. Мазур, В. А. Передрій, С. В. Дулько // Современная стоматология. - 2010. № 5. - С. 47-52.

7. Державний реєстр лікарських засобів України [Електронний ресурс]. - Режим доступу : http://www.drlz.com.ua/.

8. Довідник «Компендіум». [Електронний ресурс]. Режим доступу: http://compendium.com.ua

ISSN 2312-0967. Pharmaceutical review. 2018. № 1 
Фармацевтичний менеджмент, маркетинг та логістика Pharmaceutical management, marketing and logistics

\section{References}

1. Kobets MM, Kobets MM [Studying the competitiveness of dental drugs]. Scientific and technological progress and optimization of technological processes for the development of medicinal products: materials of the 5th science. conf. from international Participation, Ternopil, September 27-28, 2013:245-6. Ukrainian.

2. Melnyk AL, Dovha IM, Khrystian HY. [Integral characteristics of infectious and inflammatory diseases of the ora cavity]. Klinichna ta eksperementalna patolohiia. 2015;1: 215-20. Ukrainian.

3. Zabolotnyi TD. Generalized periodontitis [Генералізований пародонтит] Lviv: GalDent; 2011. Ukrainian.

4. Shulha LI, Beztsenova TS, Piminov OF, Rolik SM,
Yakushchenko VA. [Research of the range of dental drugs presented in the pharmaceutical market of Ukraine] Zaporizhzhia Medical Journal. 2012;5: 110-13. Ukrainian.

5. Lukashiv OI Vronska LV, Benzel IL [Research of the range of medicinal products on a vegetative basis for local application in dentistry and lore-practice]. Farmats zhurn. 2013;1: 146-51. Ukrainian.

6. Mazur IP, Peredry VA, Dulko SV. [Pharmacological means for local treatment of periodontal] Sovremennaya stomatologiya. 2010;5: 47-52. Ukrainian.

7. Derzhavnyi reiestr likarskykh zasobiv Ukrainy. [Electronic resource]. Available from: http://www.drlz.com.ua/.

8. Kompendium. [Довідник «Компендіум»] [Electronic resource]. Available from: http://compendium.com.ua/

Отримано 05.02.2018 